\title{
Difficulties and facilities for notification of sexual partners with sexually transmitted infections
}

\author{
Dificuldades e facilidades para notificação de parceiros sexuais com infecções sexualmente \\ transmissíveis
}

Elani Graça Ferreira Cavalcante ${ }^{1}$, Ivana Cristina Vieira de Lima ${ }^{1}$, Ana Karina Bezerra Pinheiro ${ }^{1}$, Mahara Coelho Crisostomo Miranda ${ }^{1}$, Marli Teresinha Gimeniz Galvão ${ }^{1}$

\begin{abstract}
Objective: to understand the difficulties and facilities of professionals to notify sexual partners with sexually transmitted infections. Methods: qualitative study carried out with 19 professionals from four referral services in sexually transmitted infections. A semistructured interview was conducted and the statements were analyzed through Content Analysis technique. Results: the difficulties identified were: diversity of types of sexual relationships, resistance of the index patient, emphasis on information transmission, ineffective verbal communication, insufficient time and absence of monitoring. The facilities were: respect for patient autonomy, counseling free of judgments, effective verbal communication, motivation and negotiation, written communication, confidential environment, partnership with the multiprofessional team, communication through card to evaluate effectiveness of notification. Conclusion: based on the competencies, communication was identified as a facilitator of empowerment of the index patient in the process of to reveal the infection to the contacts, and weaknesses emerged in the conduct of cases about the knowledge, planning, implementation, partnership and evaluation.
\end{abstract}

Descriptors: Contact Tracing; Sexually Transmitted Diseases; Sexual Partners; Health Promotion.

Objetivo: compreender as dificuldades e facilidades dos profissionais para notificação de parceiros sexuais com infecções sexualmente transmissíveis. Métodos: estudo qualitativo realizado com 19 profissionais de quatro serviços de referência em infecções sexualmente transmissíveis. Realizou-se entrevista semiestruturada e depoimentos foram analisados pela técnica da Análise de Conteúdo. Resultados: identificou-se como dificuldades: diversidade de tipos de relacionamentos sexuais, resistência do paciente-índice, ênfase na transmissão da informação, ineficácia da comunicação verbal, tempo insuficiente e ausência de monitoramento. Emergiram como facilidades: respeito à autonomia do paciente, aconselhamento livre de julgamentos, comunicação verbal efetiva, motivação e negociação, comunicação escrita, ambiente confidencial, parceria com a equipe multiprofissional, comunicação por cartão para avaliar a efetividade da notificação. Conclusão: com base nas competências, identificou-se a comunicação como meio facilitador ao empoderamento do pacienteíndice no processo de revelação da infecção aos contatos, e emergiram fragilidades na condução dos casos quanto ao conhecimento, planejamento, implementação, parceria e avaliação.

Descritores: Busca de Comunicante; Doenças Sexualmente Transmissíveis; Parceiros Sexuais; Promoção da Saúde.

$\overline{{ }^{1} \text { Universidade Federal do }}$ Ceará. Fortaleza, CE, Brazil. 


\section{Introduction}

Notification of sexual partners is an essential public health intervention for the control of Sexually Transmitted Infections (STIs), as it helps to interrupt infections and reinfections, as well as prevent complications ${ }^{(1)}$. It is a means by which STI patients, named index patient, understand the need for their sexual partners to be referred to the service for diagnosis and treatment, when necessary ${ }^{(2)}$.

This intervention is complex because of the demotivation people to reveal their infected status to their sexual partners in the face of subjective issues related to sexuality, prejudice, rejection, or feelings of guilt, shame, and fear of exposing their sexual behaviors $^{(3-4)}$. Therefore, it is recommended that professionals be aware of the safety and preference of index patients for the most effective means of communication and the challenges involved in locating partners ${ }^{(2)}$.

In this context, effective communication between professionals and index patients is an important action for the success of notification of partners. This may contribute to the empowerment of index patients about their illness and the understanding of the consequences of non-inclusion of sexual partners in the care $\operatorname{plan}^{(5)}$.

In Brazil, the Ministry of Health recommends that the approach of partners be performed by health professionals. However, a study showed that the attendance of sexual partners depends only on index patients, what may be associated with the lack of detail in the STI national protocol of the responsibilities of professionals and institutions to ensure the success of this action ${ }^{(4)}$.

In addition, a management of STI cases focused on curative, fragmented and discontinuous practice, without considering the listening and the autonomy of subjects, is observed in the country ${ }^{(6)}$. This indicates the need for training professionals to provide a more comprehensive care for infected people, especially to make them acknowledge the need to notify their par- tners as a health promotion action. This action assumes an active participation of the infected person in health care, social responsibility and incorporation of healthy lifestyles ${ }^{(7)}$.

Before the need to develop health promotion actions not only in the field of STIs, but in different areas, a list of professional competencies of health promotion has been prepared by an international advisory group of experts, in a project called Developing Competencies and Professional Standards for Health Promotion Capacity Building in Europe (CompHP)(7). This project resulted in the definition of nine domains of expected competencies to guide professionals to develop actions in an adequate, efficient and effective manner. In this definition, knowledge and ethical values, as guiding principles, are inserted in all nine domains, namely: favoring change, health advocacy, partnership, communication, leadership, diagnosis, planning, implementation, evaluation and research.

The identification of actions carried out by professionals in the scope of notification of partners of STI patients, based on essential competences, appears as a strategy to identify existing facilities and difficulties, which can provide a situational diagnosis. Thus, this study has as guiding question: what are the difficulties and facilities of professionals for notifying sexual partners of STI patients, based on the essential competences of health promotion?

In this regard, it is considered important to analyze aspects inherent in the notification of partners in the light of the essential competences of health promotion, because it allows an expanded view of how this action is being carried out in health institutions, especially face of the lack of research on this theme in the Brazill(4). In addition, this study can provide support for developing guidelines to approach partners of STI patients as a way to assist health professionals and services to increase the recruitment of sexual contacts.

Accordingly, this study aimed to understand the difficulties and facilities to notify sexual partners with sexually transmitted infections. 


\section{Methods}

This is a qualitative study carried out in four referral health units for care of STI patients in Fortaleza-CE, Brazil, from March to July 2014. A total of 19 professionals from the multiprofessional team participated in the study.

The inclusion criteria were: professional who provides care for STI patients who is responsible for the notification of sexual partners. The requirement of at least one year of professional experience in STI area was adopted in order to obtain more precise information. Intentional sampling through verbal invitation was used to select participants. The exhaustion criterion was also adopted, characterized by the inclusion of all health professionals available in the health services. Participants were identified by an alphanumeric code where the letter I of interview was followed by the sequential number of the interview (Ex.: E1).

Data was collected through a semi-structured interview conducted in the work environment of the professionals in a reserved room. The interview had the guiding question: What are the difficulties and facilities that you have when dealing with notification of sexual partners of STI patients? The professionals' testimonies were audio-taped and had an average duration of 30 minutes.

In order to obtain additional data, we used a structured form to survey the following information: professional category; age; sex; time of professional experience; attendance to courses on partner notification; ways to notify partners; establishment of deadlines for the index patients communicate their partners; prior scheduling of the partner's consultation; and knowledge about sexually transmitted infections that leads patients to communicate their partners and compulsory notification.

The participants' statements were analyzed according to the Content Analysis technique, in which the units of the text that are repeated are categorized, inferring an expression that represents them ${ }^{(8)}$. After transcription and inspection of the speeches, the fluctuating reading was started, that is, the in-depth analysis of each testimony to elaborate a scheme for interpretation of speeches. The theoretical reference of essential competences of health promotion advocated by the European project CompHP was used as basis for categorization of speeches ${ }^{(7)}$.

Results were presented in tables and analyzed according to the nine competence domains essential for the practice of health promotion: 1. Favoring change; 2 . Health advocacy; 3 . Partnership; 4. Communication; 5. Leadership; 6. Diagnosis; 7. Planning; 8. Implementation; 9. Evaluation and research. Finally, the testimonies related to each of the domains were subdivided into facilities and difficulties to notify partners. To compose the guiding axis of knowledge, we counted on information provided by professionals in the structured form.

The study complied with the formal requirements contained in the national and international regulatory standards for research involving human beings.

\section{Results}

A total of 19 professionals participated, including eight nurses, six physicians, three social workers, one psychologist and one pharmacist. They were predominantly female and older than 40 years. As for the time of experience, twelve had less than five years and seven reported more than five years. With regard to courses on notification of sexual partners, 10 professionals reported that they had not participated in any technical training.

As for the way used for notification, 17 performed it verbally, informing the index patient about the need for their sexual partners to attend the service. Two professionals said they use a communication card as strategy. In most cases, there was no establishment of a time frame for the index patient to report the infection to the sexual partner and neither was determined the time interval for the partner to attend the service. 
On infections requiring communication of sexual partners, professionals mentioned most frequently syphilis, Acquired Immunodeficiency Virus (HIV) and hepatitis B/C. Some particpants considered infections due to gonorrhea, chlamydia, urethral discharge syndrome and herpes as reasons for partners to go to the health service.

Figure 1 lists the difficulties to notify partners, namely: diversity of types of sexual relationships; resistance of the index patient; emphasis on information transmission; ineffective verbal communication; insufficient time for notification of partners and lack of monitoring of partners.

Figure 2 shows the facilities for notifying partners mentioned by professionals, namely: respect for the autonomy of the index patient; counseling free of judgments; confidential environment; couseling for effective verbal communication; motivation and negotiation; written communication; communication through card to evaluate the effectiveness of the notification; and partnership with the multiprofessional team.

\begin{tabular}{|l|c|l|}
\hline Difficulties & Related domain & \multicolumn{1}{|c|}{ Testimonials } \\
\hline $\begin{array}{l}\text { Diversity of types of } \\
\text { sexual relationships }\end{array}$ & Ethical values & $\begin{array}{l}\text { There are difficulties to notify in cases of homosexual, bisexual, casual and extramarital } \\
\text { relationships (I3). }\end{array}$ \\
\hline Index patient resistance & Ethical values & $\begin{array}{l}\text { Patient resistance to tell the partner. (I7). } \\
\text { Fear of being blamed for contracting and passing the disease on to the partner (I9) }\end{array}$ \\
\hline $\begin{array}{l}\text { Emphasis on information } \\
\text { transmission }\end{array}$ & Favoring change & $\begin{array}{l}\text { Notification becomes easier when people have the information and understand the disease } \\
\text { (I16). }\end{array}$ \\
\hline $\begin{array}{l}\text { Ineffective verbal } \\
\text { communication }\end{array}$ & Communication & $\begin{array}{l}\text { As the call happens only verbally, it is often not possible to educate the patient about the } \\
\text { importance of attending the service (I1). }\end{array}$ \\
\hline $\begin{array}{l}\text { Insufficient time for } \\
\text { notification of partners }\end{array}$ & $\begin{array}{l}\text { Planning, } \\
\text { implementation }\end{array}$ & $\begin{array}{l}\text { Little time during the consultation to motivate the patient to call the partner (I10). } \\
\text { Lack of monitoring } \\
\text { partner notification }\end{array}$ \\
\hline
\end{tabular}

Figure 1 - Difficulties to notify partners mentioned by the professionals, identified based on the CompHP domains

\begin{tabular}{|l|l|l|}
\hline Facilities & Related domain & \multicolumn{1}{|c|}{ Testimonials } \\
\hline $\begin{array}{l}\text { Respect for the au- } \\
\text { tonomy of the index } \\
\text { patient }\end{array}$ & Ethical values & The patient is requested to communicate the partner himself about the infection (I2). \\
\hline $\begin{array}{l}\text { Counseling free of } \\
\text { judgments }\end{array}$ & Communication & $\begin{array}{l}\text { Emphasis on the understanding of patients and partners of the disease and treatment not } \\
\text { instigating guilt but rather solving the problem (I2). }\end{array}$ \\
\hline $\begin{array}{l}\text { Confidential } \\
\text { environment }\end{array}$ & Communication & $\begin{array}{l}\text { Inform the patient about the secrecy of the consultation... Not even the consultation room has the } \\
\text { name infectology, so that they may not feel embarrassed (I12) }\end{array}$ \\
\hline $\begin{array}{l}\text { Counseling for effec- } \\
\text { tive verbal commu- } \\
\text { nication }\end{array}$ & Communication & $\begin{array}{l}\text { In counseling, patient must feel comfortable talking and discussing the call (I1). } \\
\text { Counseling must generate trust between patient and professional (I4). }\end{array}$ \\
\hline $\begin{array}{l}\text { Motivation and ne- } \\
\text { gotiation }\end{array}$ & Favoring change & $\begin{array}{l}\text { It is necessary to motivate the index patient to convince his partner to attend the service (I5). } \\
\text { Guiding the patient on the need of the partner to know the result in order to receive treatment } \\
\text { and have a good quality of life, regardless of the outcome (I19). }\end{array}$ \\
\hline $\begin{array}{l}\text { Written communi- } \\
\text { cation }\end{array}$ & $\begin{array}{l}\text { The use of the communication card for partners, summarising all guidances about the importance } \\
\text { of the notification (I8). } \\
\text { The communication card encourages index patients to call their partners and make partners to } \\
\text { attend the service, not necessarily in the presence of the index patient (I10). }\end{array}$ \\
\hline $\begin{array}{l}\text { Card communication } \\
\text { to evaluate the effec- } \\
\text { tiveness of the notifi- } \\
\text { cation }\end{array}$ & Evaluation and \\
research \\
$\begin{array}{l}\text { Partnership with the } \\
\text { multiprofessional } \\
\text { team }\end{array}$ & $\begin{array}{l}\text { The use of a card to communicate partners allows the professional to have control of the number } \\
\text { of people invited to attend the service, people who attended and who did not attend (I8). }\end{array}$ \\
\hline
\end{tabular}

Figure 2 - Difficulties to notify partners mentioned by professionals, identified based on the CompHP domains 


\section{Discussion}

As limitations of this study, it is worth noting that this study did not use the resource of observation of the care provided by professionals to index patients and their partners to complement the findings of the research and the impossibility to generalize the results.

The weaknesses of professionals in the field of knowledge may be associated with the report of lack of technical training in the area of STI and of specific instruction on how to approach partners. These factors may have as consequence a lower commitment of professionals in the development of this action ${ }^{(5)}$.

From the perspective of ethical values, the professionals' limitations to approach partners in homoaffective and bisexual relationships may have implications for the control of STIs, because these cases concentrate a greater number of eventual sexual partnerships and, thus, a lower possibility to locate sexual contacts, when compared to heterosexuals ${ }^{(9)}$. This finding corroborates another study that points to weaknesses in the implementation of the National Policy on Integral Health for Lesbians, Gays, Bisexuals, Transvestites and Transsexuals, because professionals provide care to this community as if they were heterosexuals ${ }^{(10)}$.

Two barriers to successful reporting have been observed in this and other surveys ${ }^{(4-5)}$ : resistance of index patients to reveal the infection to their contacts due to the fear of the partner's reaction, anger or shame; and absence of alternative methods for the professional to directly contact sexual partners.

Another weakness identified among the participants of this research was the emphasis on providing information, without discussing the individual needs and the most appropriate strategies for each case. This attitude was evident among professionals who do not receive training in this area, culminating in a minor proactivity in the notification process ${ }^{(11)}$.

With regard to the communication domain, it was considered as fragility that professionals did not mention notification alternatives other than the own index patients, who are charged the main responsible for summoning the partner to attend the service. This is not in line with international guidelines on the benefits of incorporating combined strategies for successful notification by professionals and/or index patients $^{(2,12)}$.

Insufficient time for counseling and approaching partners was pointed out as a fragility in the domain of planning and implementation domain, as also indicated by another study that highlighted the need for sufficient time to achieve successful actions ${ }^{(5)}$.

It was noted that there is no monitoring of the actual attendance of partners to the services surveyed, translating into lack of data on the effectiveness of the notification of partners. Some initiatives to evaluate the process of notification of partners have been instituted internationally. They include clinical record verification, telephone contact and implementation of integrated information systems to monitor attendance ${ }^{(12) .}$

As a facility linked to ethical values, respect for the autonomy of the index patient to communicate the sexual partner was observed. This enables the patient's participation in decision-making, especially for preserving secrecy and confidentiality ${ }^{(13)}$. However, the non-citation of the time frames for attendance of the partner makes it difficult for professionals implement other tools ${ }^{(12)}$.

We emphasize as facilities within the domain of communication the counseling free of judgments and the confidential environment for provision of care. This finding corroborates other evidences that these resources are fundamental for establishing bond and confidence between professionals and patients, and for obtaining information of intimate nature, in addition to ensuring confidentiality ${ }^{(1,3,5)}$.

Furthermore, the use of motivation and negotiation strategies in the counseling, discussing on the right of the partners to receive treatment and have a 
good quality of life, was identified as a facilitating factor in the domain of favoring changes. This is in line with a study that emphasized the motivational role played by professionals to identify sexual partners ${ }^{(5)}$.

Another facilitating strategy in the field of communication was the use of a communication card offered to the patient to deliver to the partner. A study carried out in Brazil considered the card as a means that allowed the index patient to communicate the partner without offering more information ${ }^{(4)}$. Advances in the approach of partners by professionals have been recommended in the country with the insertion of new technological tools (electronic, social networks), besides the conventional methods (correspondence, communication card, telephone contact) ${ }^{(13)}$, following the example of international experiences ${ }^{(12)}$.

Despite the favorable report of professionals about the use of communication cards as a means of monitoring partners' attendance, this form of evaluation of the notification is incipient because evaluates only the cases that received the card and attended the health service. It does not mention any intervention from professionals in situations when patients refuse to give the cards or when the partners do not come within 15 days, as recommended in national territory ${ }^{(13)}$.

In relation to the partnership domain, professionals reported only the multidisciplinary approach as a facilitating aspect to notify partners. There was no reference to intersectoriality as a strategy to expand access of partners to health services. This strategy is already functional in England, where there is additional help of a team professionals, particularly a nurses, to follow the progress of the notification of the partner by telephone and/or offer treatment to partners in credited pharmacies, with the support of a pharmacist ${ }^{(14-15)}$. Another initiative to increase the location of partners in developed countries has been the integration of primary health care services and referral clinics in STIs, through the support of specialists $^{(12)}$.

\section{Conclusion}

The present study provided evidence based on health promotion competencies that the action of notification of partners is carried out in an incipient way by professionals and without indication of advances in the incorporation of new technologies for notification of contacts. Within the domain of knowledge of professionals, limited knowledge about Sexually Transmitted Infections that require partners to attend the health unit to receive treatment was observed, as well as little knowledge on how to deal with the patient's resistance to notifying the partner.

From the perspective of planning, implementation, partnership, evaluation and research, it was identified that these actions are carried out in a punctual manner, without follow-up of the disclosure of the infection to the partner, or any mention to intersectoral actions. Among facilities, we highlight the efforts made by professionals within the domain of communication, with a view to the empowerment of index patients to reveal the infection to their contacts, through counseling strategy.

\section{Collaborations}

Cavalcante EGF and Miranda MCC contributed to the design, analysis and interpretation of data. Lima ICV and Pinheiro AKB contributed to the analysis and interpretation of data, article writing, critical review of the intellectual content and final approval of the version to be published. Galvão MTG contributed to the final approval of the version to be published.

\section{References}

1. Ward H, Bell G. Partner notification. Medicina. 2014; 42(6):314-7.

2. European Centre for Disease Prevention and Control. Public health benefits of partner notification for sexually transmitted infections and HIV. Stockholm: ECDC; 2013. 
3. Sousa LB, Pinheiro AKB. Doenças sexualmente transmissíveis na relação estável: perspectivas para o cuidado usando modelo Sunrise. Rev Rene. 2011; 12(3):478-86.

4. Cavalcante EGF, Miranda MCC, Carvalho AZFHT, Lima ICV, Galvão MTG. Partner notification for sexually transmitted infections and perception of notified partners. Rev Esc Enferm USP. 2016; 50(3):448-55.

5. Theunissen KA, Schipper P, Hoebe CJ, Crutzen R, Kok G, Dukers-Muijrers NH. Barriers to and facilitators of partner notification for chlamydia trachomatis among health care professionals. BMC Health Serv Res [Internet]. 2014 [cited 2017 Jan. 13];14:647. Available from: https:// bmchealthservres.biomedcentral.com / articles/10.1186/s12913-014-0647-5

6. Fonseca PL, Iriart AB. Aconselhamento em DST/ Aids às gestantes que realizaram o teste antiHIV na admissão para o parto: os sentidos de uma prática. Interface Comun Saúde Educ. 2012; 16(41):395-407.

7. Dempsey C, Barry M, Battel-Kirk B. The CompHP core competencies framework for health promotion handbook: workpackage. Galway: Executive Agency for Health Promotion and Consumers, National University of Ireland; 2011.

8. Bardin L. Análise de conteúdo. São Paulo: Edições 70; 2011.

9. Van AF, Van WY, Spijker R, Götz H, Op CE. Partner notification among men who have sex with men and heterosexuals with STI/HIV: different outcomes and challenges. Int J STD AIDS. 2015; 26(8):565-73.
10. Cardoso MR, Ferro LF. Saúde e população LGBT: Demandas e especificidades em questão. Psicol Ciênc Prof. 2012; 32(3):552-563.

11. Op de Coul ELM, Spijker R, Van Aar F, Van Wert Y, Bruin M, Partner Notification Group. With whom did you have sex? Evaluation of a partner notification training for STI professionals using motivational interviewing. Patient Educ Couns. 2013; 93(3):596-603.

12. Bell G, Potterat J. Partner notification for sexually transmitted infections in the modern world: a practitioner perspective on challenges and opportunities. Sex Transm Infect [Internet]. 2011 [cited 2017 Jan. 13]; 87: 34-6. Available from: http://sti.bmj.com/content/87/Suppl_2/ii34. long

13. Ministério da Saúde (BR). Protocolo Clínico e Diretrizes Terapêuticas Infecções Sexualmente Transmissíveis. Brasília: Ministério da Saúde; 2015.

14. Estcourt C, Sutcliffe L, Cassell J, Mercer CH, Copas A, James L, et al. Can we improve partner notification rates through expedited partner therapy in the UK? Findings from an exploratory trial of Accelerated Partner Therapy (APT). Sex Transm Infect. 2012; 88(1):21-6.

15. Estcourt CS, Sutcliffe LJ, Copas A, Mercer CH, Roberts TE, Jackson LJ, et al. Developing and testing accelerated partner therapy for partner notification for people with genital Chlamydia trachomatis diagnosed in primary care: a pilot randomized controlled trial. Sex Transm Infect. 2015; 91(8):548-54. 